\title{
Synthesis, Characterization and Biological Activities of Mixed Ligand Complexes of Mannich Base Derived from 2-Mercaptobenzothiazole
}

\author{
Rehab A.M. Al-Hasani and Eiman S.A. Shaheen \\ Department of Chemistry, College of Science, Al-Mustansirya University, Baghdad-Iraq.
}

\begin{abstract}
The compound (2-mercaptobenzothiazole) (2-MBT) react with formaline and dicyclohexyl amine to form new mannich base [3-dicyclohexyl amino methyl -2- mercaptobenzothiazole] [E]. The product was characterized by (FT-IR , ${ }^{1}$ H.N.M.R and C.H.N.S). (E) was used as a ligand for preparation mono ligand complexes of metal ions [Mn(II), $\mathrm{Co}(\mathrm{II}), \mathrm{Ni}(\mathrm{II}), \mathrm{Cu}$ (II) and $\mathrm{Zn}$ (II)] on the one hand and mixed ligand complexes of the same metal ions using the preparation mannich base (E) as a primary ligand and the amino acid tryptophan (Trp.) as a scondary ligand on the other hand. The prepared mono and mixed ligand complexes were isolated in the solid state and characterized by (FT-IR and Uv-Vis) Spectroscopy, (elemental analysis and flame atomic absorption) techniques as well as (magnetic susceptibility and conductivity) measurements. Based on the results of these diagnoses which showed that the metal ions was coordinated with (E) by nitrogen atom of amino methyl group and sulfer atom of thiocarbonyl group on the mono and mixed ligand complexes, in addition of coordination of (Trp.) on the mixed ligand complexes by oxygen atom of carboxyl group and nitrogen atom of the free amine group. The antibacterial activity for ligands (E and Trp.) and their mono and mixed ligand complexes were studied against two selected micro-organisms (Escherichia coil) and (staphylococcus aureus), the minimal inhibitory concentration (MIC) have been also studied to determined the low concentration for inhibition, two antibiotics (Ampicillin and Amoxicillin) have been chosen to compare their activity with those of the new compounds. The results showed higher activity of the new compounds relative to the chosen antibiotics .Furthermore the antifungl activity against two micro-organism (penicillum Spp and Aspergillus flavus) were studied for ligands (E and Trp.) and their mono and mixed ligand complexes. The results showed great enhancement of activity of the all complexes relative to that of their respective ligands. This was attributed to the synergetic effect between the metel ion and the ligand, in addition to the differences in the structural varities.
\end{abstract}

\section{Introduction}

Benzothiazole derivatives were among the various heterocyclic that have received a greet deal of attention during the last years, especially as anti microbial agents ${ }^{(1,2)}$. Most of the substitution have been carried out at the 2-and 3-positions of the benzothiazole ring ${ }^{(3-6)}$. Since 2-thion benzothiazole does contain the $(-\mathrm{N}-\mathrm{C}=\mathrm{S})$ moiety, which have hard $(\mathrm{N})$ besides soft (S) atoms and have a well established biological activity ${ }^{(4,6-9)}$. The synthesis and characterization of the mannich bases derived from heterocyclic rings and different aliphatic amines were described along with a number of their transition metal complexes ${ }^{(9,10)}$. Mixed ligand complexes of mannich bases play an important role in biological system ${ }^{(11,12)}$. In the present paper describes the preparation of a new mannich base, in attempt to introduce the amino methyl moiety in the structure mercapto benzothiazole ring which is known to passes a therapeutical applications, as well as to investigate the coordination behavior of the new derivative toward number transition metal ions by preparing mono and mixed ligand complexes and to compare the biological activity of the mannich base and their mono and mixed ligand complexes with the main ring structure.

\section{Experimental}

\section{(A) Physical measurements and analysis}

Melting points were recorded on gallenkamp Melting point apparatus and were uncorrected. FT-IR spectra were recoded using (FT-IR8300 Schimadzu in the range of (2004000) $\mathrm{cm}^{-1}$ for complexes by using (CSI disc) and Fouror transform Infrared 
spectrophotometer-shimadzu in the range of (400-4000) $\mathrm{cm}^{-1}$ for ligand by using ( $\mathrm{KBr}$ disc)). ${ }^{1}$ H.N.M.R spectra was recorded using (Bruker Spectropin Ultra Shield TM Magnets 300 MHZ) Spectrophotometer. Electronic spectra were obtained using UV-1650PC Schimadzu Spectrophotometer at room temperature, the measurements were recorded using a concentration of $\left(10^{-3} \mathrm{M}\right)$ of the complex in chloroform as a solvent. The metal content was estimated Spectrophotometerically using atomic absorption Schimadzu AA670 Spectrophotometer. The elemental analyses (C.H.N.S) were obtained using EA-034.mth. Conductivity measurements were obtained using Corning conductivity meter 220, these measurements were obtained in DMF solvent using concentration of $\left(10^{-3} \mathrm{M}\right)$ at $25 \mathrm{C}^{\circ}$. Magnetic susceptibility measurements were obtained at $25 \mathrm{C}^{\circ}$ on the solid state applying Faraday's method using Bruker BM6 instrument.

\section{(B) Material and Methods}

All chemicals were of highest purity and were used as received.

\section{1) Preparation of the mannich base $(E)$}

(E) was prepared as described in our previous work $^{(13)}$.An ethanolic solution of (2-MBT), dicyclohexyl amine and formalin were taken in $(1: 1: 1)$ mole ratio, were mixed under ice-cold condition for one hour to get the final product $(E)$, scheme (1) The physical properties of(E) are shown in Table (1). It was identified by elemental analysis (C.H.N.S), FT-IR and ${ }^{1}$ H.N.M.R. The result are shown in Table (1) and (2).

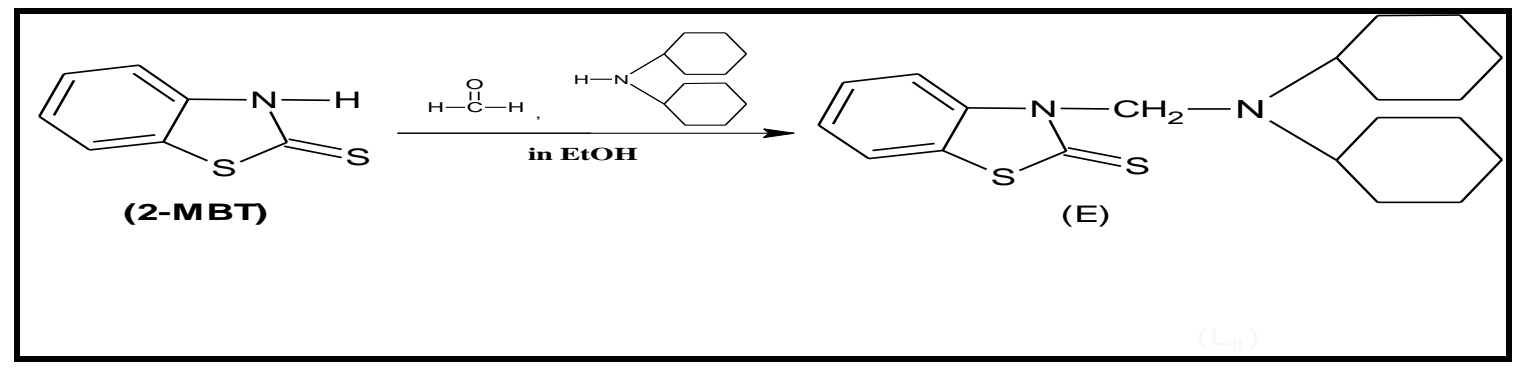

Scheme (1) Preparation of (E).

2) Preparation of the mono ligand complexes $\left(\mathbf{S}_{1}-\mathbf{S}_{5}\right)$

An Ethanolic solution of each of the following metal ions salts $(0.69$ mmole $)$ $\left[(0.137 \mathrm{gm}) \quad \mathrm{MnCl}_{2} .4 \mathrm{H}_{2} \mathrm{O}, \quad(0.16 \mathrm{gm})\right.$ $\mathrm{CoCl}_{2} .6 \mathrm{H}_{2} \mathrm{O},(0.16 \mathrm{gm}) \mathrm{NiCl}_{2} .6 \mathrm{H}_{2} \mathrm{O},(0.11 \mathrm{gm})$ $\mathrm{CuCl}_{2} .2 \mathrm{H}_{2} \mathrm{O}$ and $(0.094 \mathrm{gm}) \mathrm{ZnCl}_{2}$ ] was added to an ethanolic solution $(0.69$ mmole $)$ of $(E)$ except in the case of Mn (II) (1.38 mmole) of (E), with stirring. The mixture was heated under reflux for (2-3) hours, during this time a precipitate was formed. The product was filtered off, washed with hot ethanol, followed by cold water and then dried under vacuum. All complexes were identified by elemental analysis (C.H.N.S), flame atomic absorption, FT-IR and Uv-Vis Spectrophotometers, magnetic and conductivity measurements. The results obtained are shown in Table (1), (2) and (3).

\section{3) Preparation of the mixed ligand complexes $\left(\mathbf{S}_{6}-\mathbf{S}_{10}\right)$}

Equimolar $\quad(0.69 \mathrm{mmols}) \quad$ ethanolic solution of (E) and alkaline solution of (Trp.) $[(0.038 \mathrm{gm})$ of $\mathrm{KOH}$ was added to (0.142 gm) of (Trp.) in ethanol] were added simultaneously to anather ethanolic solution of metal ions salts $\left[(0.137 \mathrm{gm}) \mathrm{MnCl}_{2} .4 \mathrm{H}_{2} \mathrm{O}\right.$, (0.16gm) $\mathrm{CoCl}_{2} .6 \mathrm{H}_{2} \mathrm{O},(0.16 \mathrm{gm}) \mathrm{NiCl}_{2} .6 \mathrm{H}_{2} \mathrm{O}$, (0.11gm) $\mathrm{CuCl}_{2} .2 \mathrm{H}_{2} \mathrm{O}$ and $(0.09 \mathrm{gm}) \mathrm{ZnCl}_{2}$, the mixture was heated under reflux for one hour, during this time a precipitate was formed. The product was filtered and wished with hot ethanol, followed by cold water and then dried under vacuum. All complexes were identified by the same methods used with $\left(\mathrm{S}_{1}-\mathrm{S}_{5}\right)$ complexes. 


\section{4) Biological activities}

The in vitro biological screening effects of the investigated compounds were tested against selected types of bacteria which include (Escherichia coil) as gram negative and (Staphylococcus aureus) as gram positive and the fungus, (Penicillum Spp.) and (Aspergillus niger) by the Well Diffusion Method $^{(14,15)}$ using agar nutrient as the medium. Stock solutions $\left(10^{-3} \mathrm{M}\right)$ were prepared by dissolving the compounds in DMSO solution. In a typical procedure, a well was made on the agar medium inoculated with microorganisms. The well was filled with the test solution using a micropipette and the plat was incubated at $35^{\circ} \mathrm{C}$ for 72 hours. During this period, the test solution diffused and the growth of the inoculated microorganisms was affected. The second technique was to get the sensitivity of each microorganism toward the new compounds by determining the minimal inhibitory concentration (MIC) which was a achieved by using Tube Dilution Method ${ }^{(14,15)}$. The (MIC) of the new compounds for each micro-organism was measured at the lowest concentration of the compound required to inhibit the growth of this micro-organism, these tubes containing different concentrations of the new compounds were incubated at $37{ }^{\circ} \mathrm{C}$ for 45 hours and the antibiotic (Amoxcillin and Ampicillin) have been chosen to compare their activity with those of the new compounds.

\section{Results and Discussion}

\section{(A) Elemental analysis}

The interaction of mannich base (E) with the metal ions (in case of mono ligand complexes $\left.\left(\mathrm{S}_{1}-\mathrm{S}_{5}\right)\right)$ and (E and Trp.) with the same metal ions (in case of mixed ligand complexes $\left(\mathrm{S}_{6}-\mathrm{S}_{10}\right)$ under study in ethanol gave a crystalation products with different colors depending on the metal ions, Table (1). All complexes were readily soluble in $\left(\mathrm{CHCl}_{3}\right.$, DMF and DMSO) and were found to be stable toward air and moisture, as well as they were decomposed before melting. The physical analytical data of (E) and it's metal complexes $\left(\mathrm{S}_{1}-\mathrm{S}_{10}\right)$ are given in Table (1). Results obtained from elemental analysis (C.H.N.S) and flame atomic absorption are in a satisfactory agreement with the calculated values. The suggested molecular formulas also supported by spectra (FT-IR) and (Uv-Vis) analysis, furthermore magntic susceptibility and conductivity measurements.

Table (1)

Physical data for mannich base (E) and it's mono and mixed ligand complexes $\left(S_{1-} S_{10}\right)$.

\begin{tabular}{|c|c|c|c|c|c|c|c|c|c|}
\hline \multirow{2}{*}{$\begin{array}{c}\text { Comp. } \\
\text { No. }\end{array}$} & \multirow{2}{*}{ Color } & \multirow{2}{*}{$\begin{array}{c}\text { Melting } \\
\text { point }\end{array}$} & \multirow{2}{*}{$\begin{array}{c}\text { Yield } \\
\%\end{array}$} & \multicolumn{5}{|c|}{ Metal analysis found Calc. } & \multirow{2}{*}{ Suggested formula } \\
\hline & & & & $C \%$ & $H \%$ & $N \%$ & $S \%$ & $M \%$ & \\
\hline $\mathbf{E}$ & $\begin{array}{c}\text { Yellowish } \\
\text { white }\end{array}$ & $\begin{array}{l}121- \\
124\end{array}$ & 91 & $\begin{array}{l}65.87 \\
66.56\end{array}$ & $\begin{array}{l}7.38 \\
7.77\end{array}$ & $\begin{array}{l}8.04 \\
7.77\end{array}$ & $\begin{array}{l}18.23 \\
17.75 \\
\end{array}$ & - & $\mathrm{C}_{20} \mathrm{H}_{20} \mathrm{~N}_{2} \mathrm{~S}_{2}$ \\
\hline $\mathbf{S}_{\mathbf{1}}$ & $\begin{array}{c}\text { Yellowish } \\
\text { brown }\end{array}$ & 162 & 79 & $\begin{array}{l}54.76 \\
55.49 \\
\end{array}$ & $\begin{array}{l}7.23 \\
6.70 \\
\end{array}$ & $\begin{array}{l}5.91 \\
6.47 \\
\end{array}$ & $\begin{array}{l}14.66 \\
14.79 \\
\end{array}$ & $\begin{array}{l}5.98 \\
6.35 \\
\end{array}$ & {$\left[\mathrm{Mn}\left(\mathrm{C}_{20} \mathrm{H}_{20} \mathrm{~N}_{2} \mathrm{~S}_{2}\right)_{2} \mathrm{Cl}_{2}\right] \mathrm{H}_{2} \mathrm{O}$} \\
\hline $\mathbf{S}_{\mathbf{2}}$ & $\begin{array}{c}\text { Blueish } \\
\text { green }\end{array}$ & 204 & 77 & $\begin{array}{l}44.86 \\
45.59\end{array}$ & $\begin{array}{l}6.13 \\
6.08\end{array}$ & $\begin{array}{l}6.21 \\
5.32\end{array}$ & $\begin{array}{l}13.02 \\
12.16\end{array}$ & $\begin{array}{l}11.08 \\
11.19\end{array}$ & {$\left[\mathrm{Co}\left(\mathrm{C}_{20} \mathrm{H}_{20} \mathrm{~N}_{2} \mathrm{~S}_{2}\right) \mathrm{Cl}_{2}\right] .2 \mathrm{H}_{2} \mathrm{O}$} \\
\hline $\mathbf{S}_{3}$ & $\begin{array}{c}\text { Dark } \\
\text { brown }\end{array}$ & 186 & 88 & $\begin{array}{l}45.39 \\
45.56\end{array}$ & $\begin{array}{l}7.00 \\
6.08\end{array}$ & $\begin{array}{l}6.16 \\
5.32\end{array}$ & $\begin{array}{l}11.89 \\
12.16\end{array}$ & $\begin{array}{l}10.93 \\
11.15\end{array}$ & {$\left[\mathrm{Ni}\left(\mathrm{C}_{20} \mathrm{H}_{20} \mathrm{~N}_{2} \mathrm{~S}_{2}\right) \mathrm{Cl}_{2}\right] .2 \mathrm{H}_{2} \mathrm{O}$} \\
\hline $\mathbf{S}_{\mathbf{4}}$ & $\begin{array}{l}\text { Dark } \\
\text { green }\end{array}$ & 173 & 92 & $\begin{array}{l}44.88 \\
45.19\end{array}$ & $\begin{array}{l}6.00 \\
6.03\end{array}$ & $\begin{array}{l}6.09 \\
5.27\end{array}$ & $\begin{array}{l}11.69 \\
12.05\end{array}$ & $\begin{array}{l}12.03 \\
11.96\end{array}$ & {$\left[\mathrm{Cu}\left(\mathrm{C}_{20} \mathrm{H}_{20} \mathrm{~N}_{2} \mathrm{~S}_{2}\right) \mathrm{Cl}\left(\mathrm{H}_{2} \mathrm{O}\right)\right] \mathrm{Cl}\left(\mathrm{H}_{2} \mathrm{O}\right)$} \\
\hline $\mathbf{S}_{5}$ & White & 153 & 78 & $\begin{array}{l}48.18 \\
48.29\end{array}$ & $\begin{array}{l}6.11 \\
5.63\end{array}$ & $\begin{array}{l}4.96 \\
5.63\end{array}$ & $\begin{array}{l}13.02 \\
12.88\end{array}$ & $\begin{array}{l}14.03 \\
13.16\end{array}$ & {$\left[\mathrm{Zn}\left(\mathbf{C}_{20} \mathbf{H}_{20} \mathbf{N}_{2} \mathbf{S}_{2}\right) \mathbf{C l}_{2}\right]$} \\
\hline $\mathbf{S}_{6}$ & $\begin{array}{c}\text { Yellowish } \\
\text { white }\end{array}$ & 323 & 94 & $\begin{array}{l}54.04 \\
53.92\end{array}$ & $\begin{array}{l}5.92 \\
6.23\end{array}$ & $\begin{array}{l}8.08 \\
8.12 \\
\end{array}$ & $\begin{array}{l}8.94 \\
9.28 \\
\end{array}$ & $\begin{array}{l}7.86 \\
7.96 \\
\end{array}$ & {$\left[\mathrm{Mn}\left(\mathrm{C}_{20} \mathbf{H}_{20} \mathbf{N}_{2} \mathbf{S}_{2}\right)\left(\mathrm{C}_{11} \mathbf{H}_{13} \mathbf{N}_{2} \mathbf{O}_{2}\right)\left(\mathbf{H}_{2} \mathrm{O}\right)_{2}\right] \mathrm{Cl}$} \\
\hline $\mathbf{S}_{7}$ & Pink & 353 & 92 & $\begin{array}{l}54.02 \\
53.60\end{array}$ & $\begin{array}{l}5.67 \\
6.19\end{array}$ & $\begin{array}{l}7.93 \\
8.07\end{array}$ & $\begin{array}{l}8.86 \\
9.22\end{array}$ & $\begin{array}{l}8.02 \\
7.91\end{array}$ & $\begin{array}{c}{\left[\mathrm{Co}\left(\mathrm{C}_{20} \mathrm{H}_{20} \mathrm{~N}_{2} \mathrm{~S}_{2}\right)\left(\mathrm{C}_{11} \mathrm{H}_{13} \mathrm{~N}_{2} \mathrm{O}_{2}\right)(\mathrm{Cl})\left(\mathrm{H}_{2} \mathrm{O}\right)\right] \mathrm{H}_{2}} \\
\mathrm{O}\end{array}$ \\
\hline $\mathbf{S}_{8}$ & $\begin{array}{c}\text { Yellowish } \\
\text { green }\end{array}$ & 346 & 93 & $\begin{array}{l}\mathbf{5 4 . 8 9} \\
\mathbf{5 5 . 0 5}\end{array}$ & $\begin{array}{l}6.01 \\
6.07\end{array}$ & $\begin{array}{l}7.79 \\
8.29\end{array}$ & $\begin{array}{l}10.13 \\
9.47\end{array}$ & $\begin{array}{l}8.39 \\
8.69\end{array}$ & {$\left[\mathrm{Ni}\left(\mathrm{C}_{20} \mathrm{H}_{20} \mathrm{~N}_{2} \mathrm{~S}_{2}\right)\left(\mathrm{C}_{11} \mathrm{H}_{13} \mathrm{~N}_{2} \mathrm{O}_{2}\right) \mathrm{Cl}\left(\mathrm{H}_{2} \mathrm{O}\right)\right]$} \\
\hline $\mathbf{S}_{9}$ & $\begin{array}{l}\text { Light } \\
\text { green }\end{array}$ & 334 & 94 & $\begin{array}{l}53.79 \\
54.66\end{array}$ & $\begin{array}{l}6.36 \\
6.02\end{array}$ & $\begin{array}{l}9.11 \\
8.23\end{array}$ & $\begin{array}{l}8.91 \\
9.40\end{array}$ & $\begin{array}{c}10.12 \\
9.33\end{array}$ & {$\left[\mathrm{Cu}\left(\mathrm{C}_{20} \mathrm{H}_{20} \mathrm{~N}_{2} \mathrm{~S}_{2}\right)\left(\mathrm{C}_{11} \mathrm{H}_{13} \mathrm{~N}_{2} \mathrm{O}_{2}\right) \mathrm{Cl}\left(\mathrm{H}_{2} \mathrm{O}\right)\right]$} \\
\hline $\mathbf{S}_{10}$ & White & 311 & 86 & $\begin{array}{l}\mathbf{5 6 . 2 3} \\
\mathbf{5 5 . 9 8}\end{array}$ & $\begin{array}{l}\mathbf{5 . 8 0} \\
5.87\end{array}$ & $\begin{array}{l}7.88 \\
8.43\end{array}$ & $\begin{array}{c}10.12 \\
9.63\end{array}$ & $\begin{array}{l}9.31 \\
9.84\end{array}$ & {$\left[\mathrm{Zn}\left(\mathrm{C}_{20} \mathrm{H}_{20} \mathrm{~N}_{2} \mathrm{~S}_{2}\right)\left(\mathrm{C}_{11} \mathrm{H}_{13} \mathrm{~N}_{2} \mathrm{O}_{2}\right)\left(\mathrm{H}_{2} \mathrm{O}\right) \mathrm{Cl}\right] \mathrm{H}_{2} \mathrm{O}$} \\
\hline
\end{tabular}




\section{(B) Proton nuclear magnetic resonance spectra of $(\mathbf{E})$}

The nuclear magnetic resonance spectra of the newly synthesized ligand gave a satisfactory spectro data and the molecular structure was assigned on the basis of ${ }^{1}$ H.N.M.R chemical shifts. The spectra was determined in DMSO solution as an internal reference. According to the results obtained from the chemical shifts spectra, the molecular structure of the ligand can be illustrated ${ }^{(9,16)}$, Fig.(1).
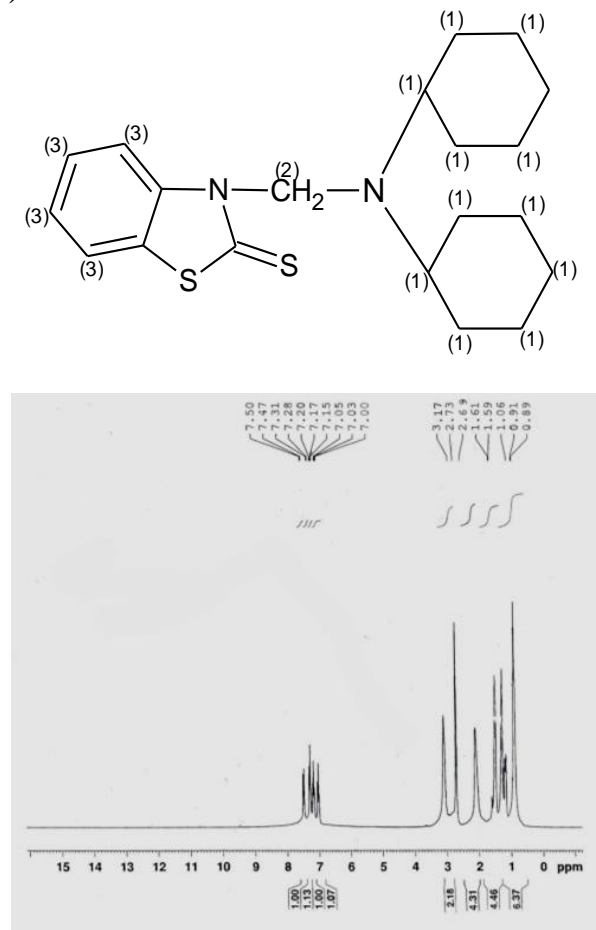

$\delta \mathrm{H}_{1}=1.06-2.73 \mathrm{ppm}(22 \mathrm{H}, \mathrm{m}$,
$\delta \mathrm{H}_{2}=3.28 \operatorname{ppm}\left(2 \mathrm{H}, \mathrm{S},-\mathrm{CH}_{2^{-}}\right)$

$\delta \mathrm{H}_{3}=6.93-7.44 \mathrm{ppm}(4 \mathrm{H}, \mathrm{m}, \square)$

Fig.(1) ${ }^{1} \mathrm{H}-\mathrm{NMR}$ of $(\mathrm{E})$.

\section{(c) Infrared spectroscopic study}

The FT-IR spectra of the free ligand showed bands due to $v_{\mathrm{C}=\mathrm{S}}, v_{\mathrm{N}-\mathrm{C}=\mathrm{S}}, v_{\mathrm{CH} 2 \mathrm{~N}}$ and $v_{\mathrm{C}-\mathrm{N}}$ which were observed at $(1047,1056)$, $(1373,1595), \quad(2935,2854)$ and $(981) \mathrm{cm}^{-1}$ respectively ${ }^{(17,18)}$. The (E) exhibit different of coordination patterns as shown by their FT-IR spectral changes. Table (2), Fig.((2,3) and (4))

1-In the complexes $\left(\mathrm{S}_{1}-\mathrm{S}_{10}\right)$, the band due to $v_{\mathrm{C}=\mathrm{S}}$ was shifted to higher frequencies, Table (2), while the observed change in the two bands due to $v_{\mathrm{N}-\mathrm{C}=\mathrm{S}}$ group, where the first band has suffered red shift, the second band was removed in some complexes to lower frequencies and others about higher frequencies (Table (2)), indicating of thiocarbonyl in the coordination ${ }^{(18,19)}$.

2-Observed a change in shape of the two bands fortresses of aminomethyl group $v_{\mathrm{CH} 2 \mathrm{~N}}$ with change in site the first band where shifted towards lower frequencies, while the band of $v_{\mathrm{C}-\mathrm{N}}$ in the aminomethyl group was shifted to higher frequencies $^{(17,20)}$.

3-In the mixed ligand complexes $\left(\mathrm{S}_{6}-\mathrm{S}_{10}\right)$, The $v_{(\mathrm{NH} 2) \text { asy., sym. }}$ Bands of free amino acid (Trp.) observed at $(3079,3039) \mathrm{cm}^{-1}$ respectively $^{(21)}$, is shifted to higher wave number, this reveals that the amino group is coordinated through nitrogen atom with the metal ions ${ }^{(19,22)}$. A band observed at

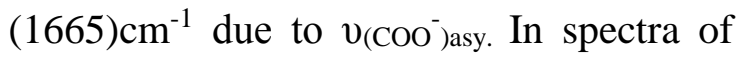
(Trp.), was shifted to lower wave number in the spectra of mixed ligand complexes, representing coordination of carboxylic group with metal ions through the oxygen atom $^{(17,23)}$.

4-A broad bands were observed around (3394-3530) $\mathrm{cm}^{-1}$ in spectra of some mono and mixed ligand complexes, assigned as $v_{\mathrm{OH}}$ suggested the presence of water molecule in the complexes ${ }^{(17)}$.

5-Some new bands of weak intensity observed may be ascribed to $v_{\mathrm{M}-\mathrm{N}}, \mathrm{v}_{\mathrm{M}-\mathrm{Cl}}$, $v_{M-S}$ and $v_{M-O}$ which are absent in the spectra obtained for the ligands ${ }^{(20,24)}$. 


\section{Table (2)}

Stretching vibrational frequencies $\left(\mathrm{cm}^{-1}\right)$ located in the FT-IR spectra of (E,Trp.) and itś mono and mixed ligand complexes:

\begin{tabular}{|c|c|c|c|c|c|c|c|c|c|c|c|}
\hline $\begin{array}{c}\text { Comp. } \\
\text { No. }\end{array}$ & $v C=S$ & $v_{N-C}=S$ & $\mathrm{VCH}_{2 \mathrm{~N}}$ & $v_{C-N}$ & $\begin{array}{l}\text { vсоо- } \\
\text { asy. } \\
\text { sym. }\end{array}$ & $\begin{array}{l}v_{N H 2} \\
\text { asy. } \\
\text { sym }\end{array}$ & $v_{M-N}$ & $v_{M-C l}$ & $v_{M-S}$ & $v_{M-O}$ & $\begin{array}{c}\text { vo-H } \\
/ \rho O-H \\
\text { of } \mathrm{H}_{2} \mathrm{O}\end{array}$ \\
\hline$E$ & $\begin{array}{l}1047, \\
1056\end{array}$ & $\begin{array}{l}1373, \\
1595\end{array}$ & $\begin{array}{l}2935, \\
2854 \\
\end{array}$ & 981 & - & - & - & - & - & - & - \\
\hline$S_{1}$ & 1074 & $\begin{array}{c}1425, \\
1554\end{array}$ & 2922 & 1006 & - & - & 530 & 407 & 435 & - & $\begin{array}{c}3394 \\
-\end{array}$ \\
\hline$S_{2}$ & 1087 & $\begin{array}{l}1361, \\
1558\end{array}$ & 2925 & 1020 & - & - & 505 & 372 & 428 & - & $\begin{array}{c}3427 \\
-\end{array}$ \\
\hline$S_{3}$ & 1082 & $\begin{array}{c}1385 \\
1579\end{array}$ & 2925 & 1028 & - & - & 540 & 391 & 428 & - & $\begin{array}{c}3450 \\
-\end{array}$ \\
\hline$S_{4}$ & 1080 & $\begin{array}{c}1427, \\
1558\end{array}$ & 2924 & 1006 & - & - & 500 & 372 & 434 & 470 & $\begin{array}{c}3452 \\
947\end{array}$ \\
\hline$S_{5}$ & 1085 & $\begin{array}{l}1361, \\
1566\end{array}$ & 2929 & 1024 & - & - & 542 & 393 & 430 & - & - \\
\hline Trp. & - & - & - & - & $\begin{array}{l}1665 \\
1410 \\
\end{array}$ & $\begin{array}{l}3079 \\
3039 \\
\end{array}$ & - & - & - & - & - \\
\hline$S_{6}$ & 1093 & $\begin{array}{l}1329, \\
1581\end{array}$ & 2925 & 1037 & $\begin{array}{l}1616 \\
1410 \\
\end{array}$ & $\begin{array}{l}\mathbf{3 3 4 2} \\
\mathbf{3 2 7 7} \\
\end{array}$ & 590 & - & 426 & 511 & $\begin{array}{c}3489 \\
988 \\
\end{array}$ \\
\hline$S_{7}$ & 1093 & $\begin{array}{c}1356, \\
1591\end{array}$ & 2928 & 1056 & $\begin{array}{l}1635 \\
1411\end{array}$ & $\begin{array}{l}3340 \\
3282\end{array}$ & 536 & 372 & 426 & 462 & $\begin{array}{c}3530 \\
997\end{array}$ \\
\hline$S_{8}$ & 1095 & $\begin{array}{c}1356, \\
1564\end{array}$ & 2927 & 1053 & $\begin{array}{l}1593 \\
1410\end{array}$ & $\begin{array}{l}3342 \\
3284\end{array}$ & 545 & 347 & 422 & 462 & $\begin{array}{c}3525 \\
997\end{array}$ \\
\hline$S_{9}$ & 1098 & $\begin{array}{l}1350, \\
1572\end{array}$ & 2908 & 1008 & $\begin{array}{l}1624 \\
1412 \\
\end{array}$ & $\begin{array}{l}3338 \\
3271 \\
\end{array}$ & 543 & 370 & 396 & 469 & $\begin{array}{c}3530 \\
940 \\
\end{array}$ \\
\hline$S_{10}$ & 1087 & $\begin{array}{c}1340, \\
1580\end{array}$ & 2927 & 1003 & $\begin{array}{l}1618 \\
1410\end{array}$ & $\begin{array}{l}3323 \\
3281\end{array}$ & 536 & - & 424 & 462 & - \\
\hline
\end{tabular}

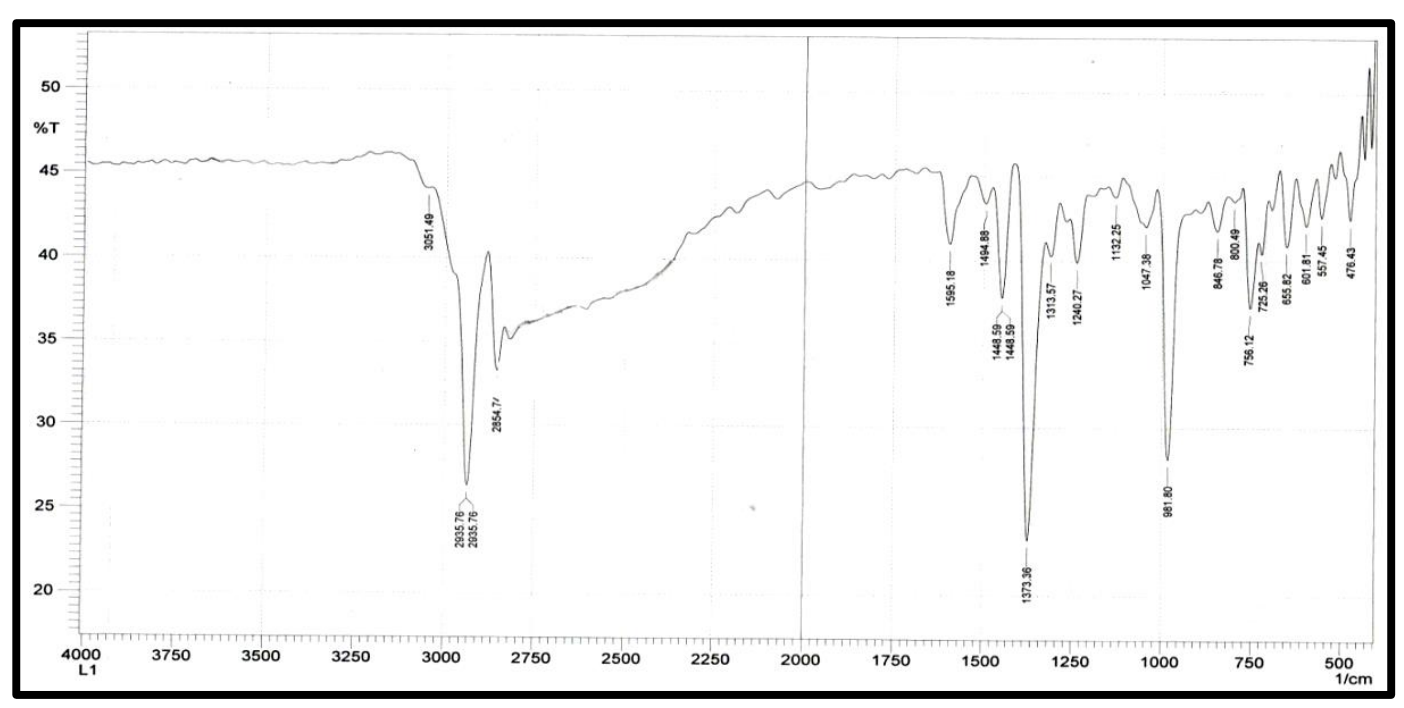

Fig.(2) IR-Spectra of (E). 


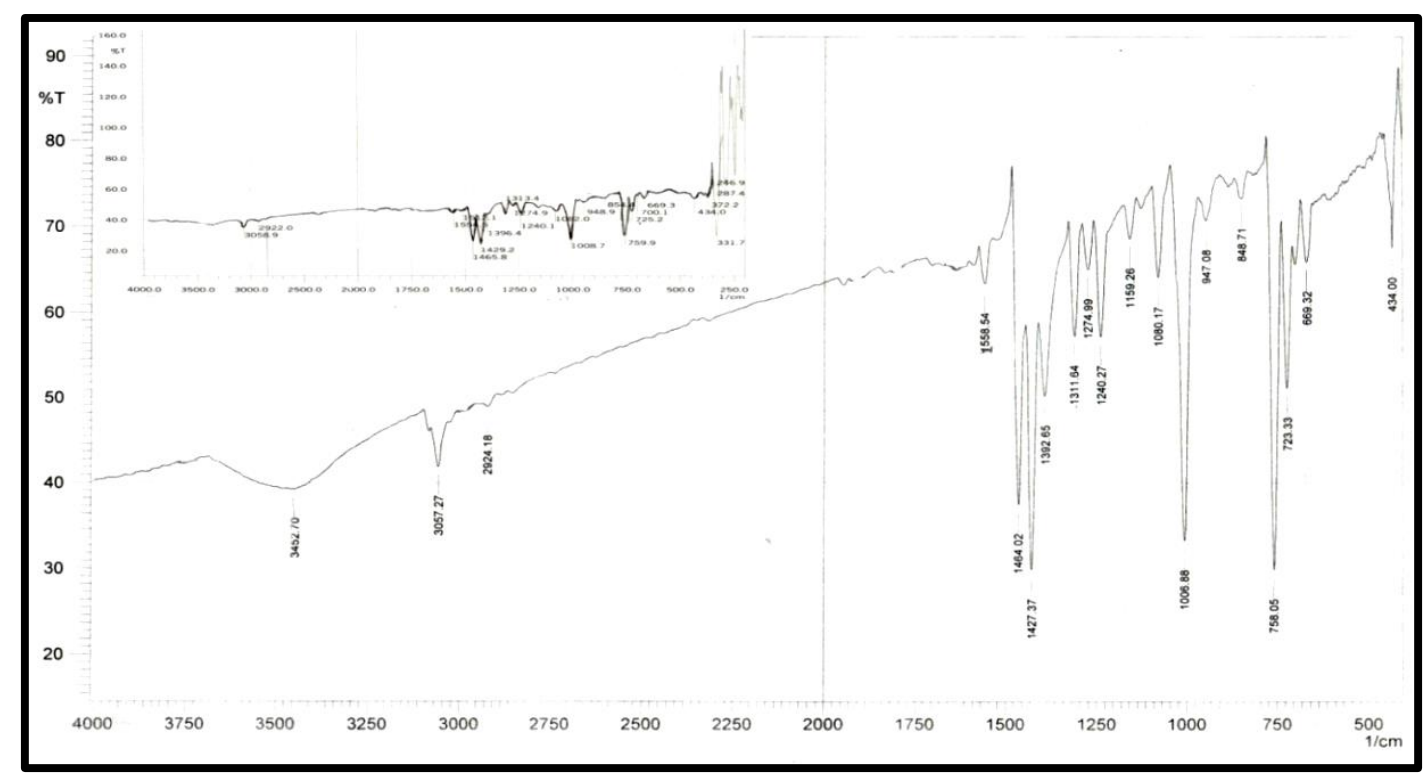

Fig.(3) FT-IR Spectra of $S_{4}$.

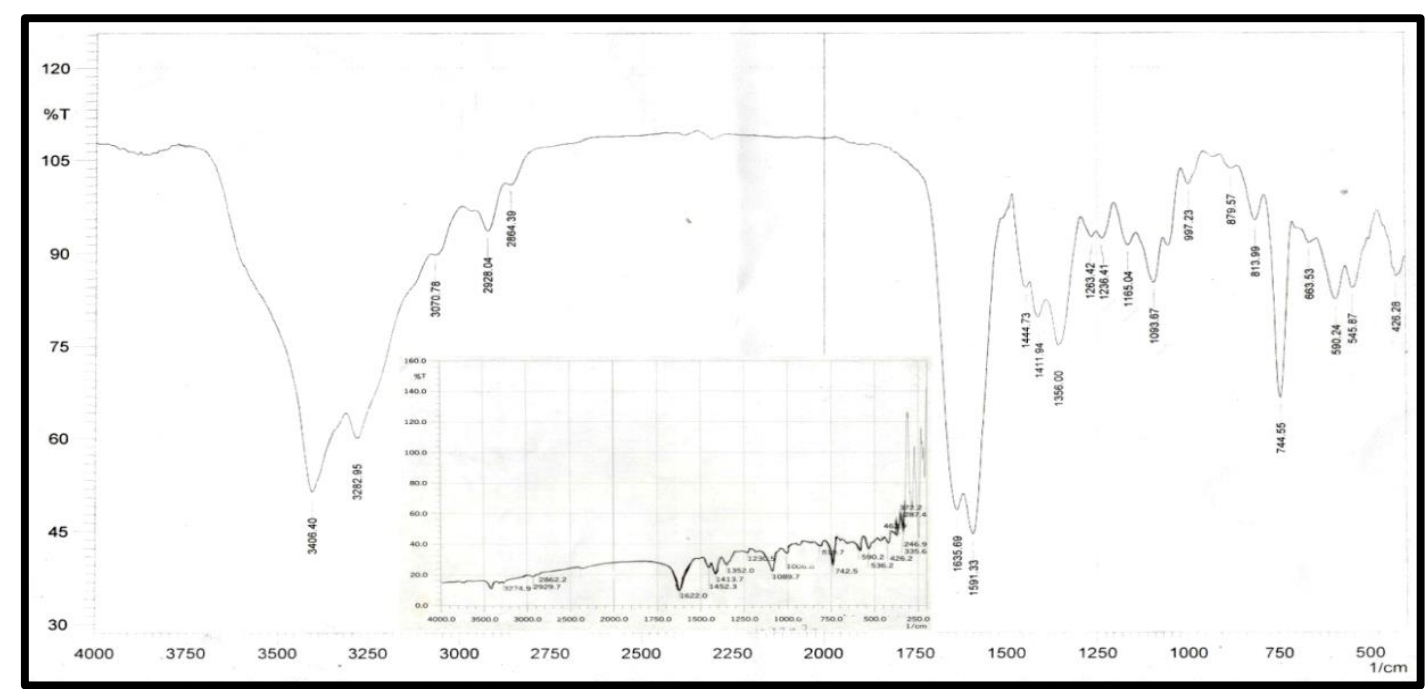

Fig.(4) FT-IR Spectra of $S_{7}$.

(D) Electronic absorption Spectra, Magnetic susceptibility and Conductivity measurement

The electronic spectra of the mono and mixed ligand complexes $\left(\mathrm{S}_{1}-\mathrm{S}_{10}\right)$ were recorder their solution in chloroform in the range of (200-900)nm, Table (3), Fig.((5) and (6)).

$\mathrm{S}_{\mathbf{1}}$ :The Uv-Vis spectrum of the yellowish brown complex show two main absorbation bands at (20294 and 29674) $\mathrm{cm}^{-1}$,which indicate an octahedral geometry ${ }^{(25)}$. The valus of racah parameters $\left(10 \mathrm{Dq}, \mathrm{B}, \beta\right.$ and $v_{1}$ ) have been calculated to be $\left(12238 \mathrm{~cm}^{-1}, 844,0.98\right.$ and $\left.11816 \mathrm{~cm}^{-1}\right)$, respectively. The effective magnetic moment at room temperature was found to be (5.02B.M), which agree well for low-spin manganese in octahedral coordination ${ }^{(26)}$. Conductivity measurment showed that the complex was to be non ionic. Table (3).

$\mathbf{S}_{\mathbf{2}}$ : The measured magnetic moment was (4.62B.M) this show the cobalt ion it's bluish green complex to be paramagnetic with $\left(\mathrm{d}^{7}\right)$ configuration in a tetrahedral geometry ${ }^{(26)}$. The electronic spectrum of cobalt complex shows three bands at $\left(14514,16667\right.$ and 19802) $\mathrm{cm}^{-1}$, these bands have been assigned to the transition $\quad{ }^{4} \mathrm{~A}_{2} \rightarrow{ }^{4} \mathrm{~T}_{1} \quad(\mathrm{P}){ }^{(13,27)}$. Assuming tetrahedral symmetry around Co (II) ion. The values of racah parameters $\left(10 \mathrm{Dq}, \mathrm{B}^{\prime}, \beta\right.$ and $\left.v_{2}\right)$ have been calculated to be $\left(3769.2 \mathrm{~cm}^{-1}\right.$, $698,0.62$ and $\left.6310 \mathrm{~cm}^{-1}\right)$ respectively. The value of $\beta(0.62)$ signifies a fair a mount of covaleat character in metal to nitrogen and sulfer bonds. While the value of (10Dq) to be 
(3769.2) $\mathrm{cm}^{-1}$, one should expect aband due the transition ${ }^{4} \mathrm{~A}_{2} \rightarrow{ }^{4} \mathrm{~T}_{2}(\mathrm{~F})$ in the infrared region at (3749) $\mathrm{cm}^{-1}$, which couldn't to be observed in the spectrum of the cobalt (II) complex ${ }^{(11)}$. Conductivity in DMF showed that the complex was non ionic, Table (3).

S3: The electronic spectrum of nickel (II) complex exhibits two main absorption band, Table (3) which are assigned to the two transition $\quad{ }^{1} \mathrm{~A}_{1} \mathrm{~g} \rightarrow{ }^{1} \mathrm{~A}_{2} \mathrm{~g}$ and $\quad{ }^{1} \mathrm{~A}_{1} \mathrm{~g} \rightarrow{ }^{1} \mathrm{Eg}$ respectively in the a square-planer geometry $(25,28)$. Magnetic moment of the complex (0.08B.M) is higher than spin value of the nickel metal only, this result indicate a orbital contribution $^{(26)}$. Conductivity measurement showed that the complex was non ionic. Table (3).

S4: The Uv-Vis spectrum of copper complex in chloroform solution displays a broad band at $11161 \mathrm{~cm}^{-1}$ and a well-defined shoulder a round $23809 \mathrm{~cm}^{-1}$, attributable to ${ }^{2} \mathrm{~B}_{1} \mathrm{~g} \rightarrow{ }^{2} \mathrm{Eg}$ and ${ }^{2} \mathrm{~B}_{1} \mathrm{~g} \rightarrow{ }^{2} \mathrm{~A}_{1} \mathrm{~g}$ transitions which strongly favour square-planar geometry a round the central metal ion ${ }^{(25,29)}$. The broadness of the band can be taken as an indication of distortion from perfect planar symmetry. This is further supported by the magnetic susceptibility value (2.05B.M). Conductivity measurement showed the complex was ionic, Table (3).

$\mathbf{S}_{5}$ and $\mathbf{S}_{10}$ : The complexes of zinc (II) are colorless and was diamagnetic as expected for $\left(\mathrm{d}^{10}\right)$ ion, since the Uv-Vis spectra of the band position was compared with that of the ligand only. The conductivity measurements indicate a non ionic behavior, Table (3). Thus from the data obtained from FT-IR spectrum and flame atomic absorption, atetrahedral geometry a round $\mathrm{Zn}$ (II) ion ${ }^{(25)}$.

S6: The brown manganese complex show two absorption bands which were observed at (15385 and 19920) $\mathrm{cm}^{-1}$. The spectrum was a typical of octahedral Mn (II) complex ${ }^{(25,30)}$.The values of racah parameters $\left(10 \mathrm{Dq}, \mathrm{B}^{\prime}, \beta\right.$ and $v_{3}$ ) have been calculated to be $\left(11313 \mathrm{~cm}^{-1}\right.$, $839,0.97$ and $\left.29690 \mathrm{~cm}^{-1}\right)$ respectively. The $\mu$ eff value Table (3), which agree well for lowspin $^{(27)}$, conductivity measurement showed that the complex was to be ionic, Table (3).

S7: The prepared bink complex showed two bands at (15385 and 18450) $\mathrm{cm}^{-1}$, which indicate an octahedral geometry ${ }^{(31)}$. These bands have been assigned to the transition ${ }^{4} \mathrm{~T}_{1} \mathrm{~g} \rightarrow{ }^{4} \mathrm{~A}_{2} \mathrm{~g}(\mathrm{~F})$ and ${ }^{4} \mathrm{~T}_{1} \mathrm{~g} \rightarrow{ }^{4} \mathrm{~T}_{1} \mathrm{~g}(\mathrm{P})$, the values of racah parameters (10Dq, $\mathrm{B}^{\prime}, \beta$ and $v_{1}$ ) have been calculated to be $\left(9450 \mathrm{~cm}^{-1}, 700,0.72\right.$ and $8100 \mathrm{~cm}^{-1}$ ) respectively. Magnetic moment of solid complex, Table (3) showed a higher orbital contribution $^{(26)}$. Conductivity in DMF showed that the complex was to be ionic, Table (3).

S8: The solution spectrum of the yellowish green exhibits intense bands at (12987, 14425 and 24525$) \mathrm{cm}^{-1}$. The position of these bands is agreement with that reported for octahedral geometry ${ }^{(32)}$. The effective magnetic moment at room temperature was found to be (3.25B.M), which agree well with octahedral geometry around $\mathrm{Ni}(\mathrm{II})$ complex $^{(26)}$, conductivity measurement showed that the complex was non ionic, Table (3).

S9: The electronic spectrum of copper (II) complex show one band at $(16949) \mathrm{cm}^{-1}$, this band has been assigned to the transition ${ }^{2} \mathrm{Eg} \rightarrow{ }^{2} \mathrm{~T}_{2} \mathrm{~g}$ which indicate an octahedral geometry ${ }^{(33)}$. Magnetic moment of solid complex, Table (3) showed a higher orbital contribution. Coductivity in DMF showed that the complex was to be non ionic, Table (3). 
Rehab A.M. Al-Hasani

Table (3)

Electronic spectra $\left(\mathrm{CHCl}_{3}\right)$, Magnetic moment (B.M) and Conductance in (DMF) for mono and mixed ligand complexes.

\begin{tabular}{|c|c|c|c|c|c|c|c|c|c|}
\hline Symb. & $\begin{array}{l}\text { Maximum } \\
\text { absorption } \\
v_{\max }\left(\mathrm{cm}^{-1}\right)\end{array}$ & Band assignment & $\boldsymbol{B}$ & $B^{\prime}$ & $\boldsymbol{B}$ & $10 D q$ & $\begin{array}{l}\text { Molar } \\
\text { Cond. } \\
\text { S.cm } \\
\text { mol }^{-1}\end{array}$ & $\begin{array}{l}\mu e f f . \\
B . M\end{array}$ & $\begin{array}{l}\text { Suggested } \\
\text { geometry }\end{array}$ \\
\hline$S_{1}$ & $\begin{array}{c}11816 \text { (Cal.) } \\
20294 \\
29674 \\
36765 \\
\end{array}$ & $\begin{array}{c}{ }^{6} \mathrm{~A}_{1} g \rightarrow{ }^{4} \mathrm{~T}_{1} g(G) \\
{ }^{6} \mathrm{~A}_{1} \mathrm{~g}(\mathrm{~S}) \rightarrow{ }^{4} \mathrm{~T}_{2} \mathrm{~g}(G) \\
{ }^{6} \mathrm{~A}_{1} \mathrm{~g}(\mathrm{~S}) \rightarrow{ }^{4} \mathrm{~A}_{1} \mathrm{~g}+{ }^{4} \mathrm{Eg}(G) \\
\text { C.T }\end{array}$ & 860 & 844 & 0.98 & 12238 & 11.36 & 5.02 & O.h \\
\hline$S_{2}$ & $\begin{array}{c}3749 \\
6310 \text { (Cal.) } \\
16994\end{array}$ & $\begin{aligned}{ }^{4} \mathbf{A}_{2} \rightarrow{ }^{4} \mathbf{T}_{2}(\mathbf{P}) \\
{ }^{4} \mathbf{A}_{2} \rightarrow{ }^{4} \mathbf{T}_{2}(\mathbf{F}) \\
{ }^{4} \mathbf{A}_{2} \rightarrow{ }^{4} \mathbf{T}_{1}(\mathbf{P})\end{aligned}$ & 1120 & 698 & 0.62 & 3769.2 & 18.05 & 4.62 & T.h \\
\hline$S_{3}$ & $\begin{array}{l}16129 \\
23310\end{array}$ & $\begin{array}{c}{ }^{1} \mathbf{A}_{1} \mathbf{g} \rightarrow{ }^{1} \mathbf{A}_{2} \mathbf{g} \\
{ }^{1} \mathbf{A}_{1} \mathbf{g} \rightarrow{ }^{1} \mathbf{E g}\end{array}$ & - & - & - & - & 12.11 & 0.08 & S.p \\
\hline$S_{4}$ & $\begin{array}{l}11161 \\
23809\end{array}$ & $\begin{array}{c}{ }^{2} B_{1} g \rightarrow{ }^{2} \mathrm{Eg} \\
{ }^{2} \mathrm{~B}_{1} g \rightarrow^{2} \mathrm{~A}_{1} \mathrm{~g}\end{array}$ & - & - & - & - & 84.02 & 2.05 & S.p \\
\hline$S_{5}$ & - & - & - & - & - & - & \begin{tabular}{ll|l}
13.44 \\
\end{tabular} & 0.0 & T.h \\
\hline$S_{6}$ & $\begin{array}{c}15385 \\
19920 \\
29690(\text { Cal. }) \\
\end{array}$ & $\begin{array}{c}{ }^{6} \mathrm{~A}_{1} \mathrm{~g}(\mathrm{~S}) \rightarrow{ }^{4} \mathrm{~T}_{1} \mathrm{~g}(\mathrm{G}) \\
{ }^{6} \mathrm{~A}_{1} \mathrm{~g}(\mathrm{~S}) \rightarrow{ }^{4} \mathrm{~T}_{2} \mathrm{~g}(\mathbf{G}) \\
{ }^{6} \mathrm{~A}_{1} \mathrm{~g}(\mathrm{~S}) \rightarrow{ }^{4} \mathrm{~A}_{1} \mathrm{~g}(\mathbf{G})+{ }^{4} \mathrm{Eg}(\mathbf{G}) \\
\end{array}$ & 860 & 839 & 0.97 & 11313 & 68.39 & 5.17 & O.h \\
\hline$S_{7}$ & $\begin{array}{c}8100 \text { (Cal.) } \\
15385 \\
18450 \\
\end{array}$ & $\begin{array}{r}{ }^{4} \mathbf{T}_{1} g \rightarrow{ }^{4} \mathbf{T}_{2} g(\mathbf{F}) \\
{ }^{4} \mathbf{T}_{1} g \rightarrow{ }^{4} \mathbf{A}_{2} g(\mathbf{F}) \\
{ }^{4} \mathbf{T}_{1} g \rightarrow{ }^{4} \mathbf{T}_{1} g(P)\end{array}$ & 971 & 700 & 0.72 & 9450 & 10.68 & 4.93 & O.h \\
\hline$S_{8}$ & $\begin{array}{c}12987, \\
10715 \text { (Cal.) } \\
14425 \\
24525\end{array}$ & $\begin{array}{l}{ }^{3} \mathbf{A}_{2} g \rightarrow{ }^{3} \mathbf{T}_{2} g(F) \\
{ }^{3} \mathbf{A}_{2} g \rightarrow{ }^{3} \mathbf{T}_{1} g(F) \\
{ }^{3} \mathbf{A}_{2} g \rightarrow{ }^{3} \mathbf{T}_{1} g(P)\end{array}$ & 1130 & 824.3 & 0.73 & 10633 & 14.93 & 3.25 & O.h \\
\hline$\overline{S S_{9}}$ & 16949 & ${ }^{2} \mathrm{Eg} \rightarrow{ }^{2} \mathbf{T}_{2} \mathrm{~g}$ & - & - & - & - & \begin{tabular}{c|c|}
11.64 \\
\end{tabular} & 1.89 & O.h \\
\hline$S_{10}$ & - & - & - & - & - & - & 66.69 & 0.0 & T.h \\
\hline
\end{tabular}

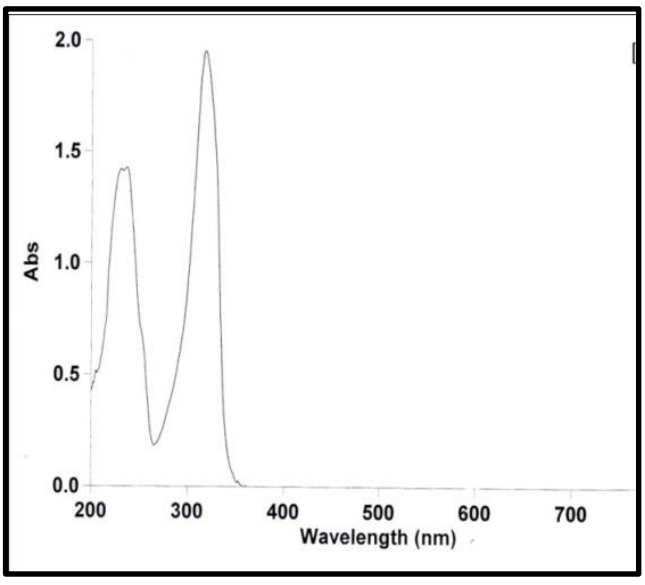

Fig.(5) UV-VIS. of $(E)$.

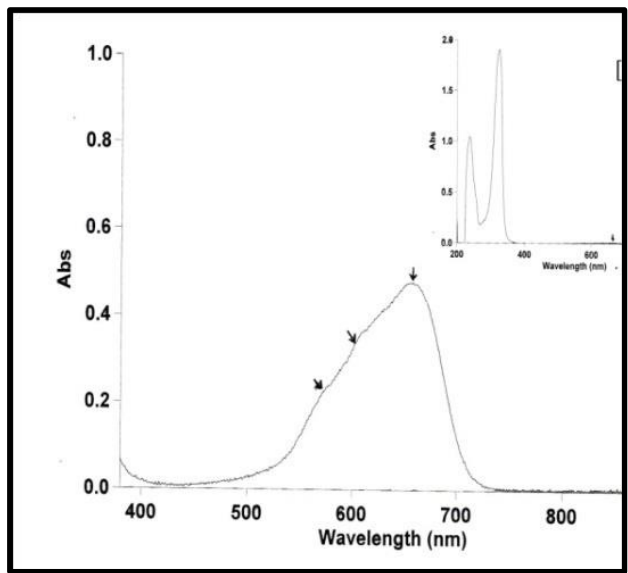

Fig.(6) UV-VIS. of $\left(S_{2}\right)$. 


\section{Biological Studies}

The free ligands ( $\mathrm{E}$ and Trp.) and their mono and mixed ligand complexes (S1-S10) were screened in vitro for their ability to inhibit the growth of representative [(E.coli) as gram negative] and [(Staph. aureus) as gram positive]. Furthermore the (MIC) study for the ligands (E and Trp.) and their metal complexes (S1-S10) are shown in Table (5). Also the study was done against (Aspergillus flaveus and penicillum Spp) fungus, in DMSO as a solvent, Table (4).

As a result from the above mentioned studies, the following points were concluded:-

a). (E) was active against Staph., while not active against E.coli , compared with (Trp.) which active against both types of bacteria, Table(4).

b). All mono ligand complexes $\left(\mathrm{S}_{1}-\mathrm{S}_{5}\right)$ showed highly active against two types of bacteria compared the ligand active prepared them, while the mixed ligand complexes $\left(\mathrm{S}_{6}-\mathrm{S}_{10}\right)$ showed high active compared to mono ligand complexes, as well as on the active of ligands (E and Trp.), Table (4).

c).The results of the (MIC) study are shown in Table (5), these result indicate that, both mono and mixed ligand complexes were more active than ligands ( $\mathrm{E}$ and Trp.) where can complexes inhibiting the growth of

\section{Table (4)}

Antibacterial and antifungal activities for Mannich base and tryptpphan and their mono and

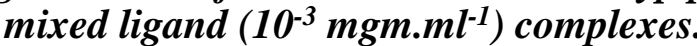

\begin{tabular}{|c|c|c|c|c|}
\hline Comp. No. & E. coli & Staph. Aureus & Asp. Flavus & Penci. SPP. \\
\hline Control DMSO & - & - & - & - \\
\hline $\mathbf{E}$ & - & 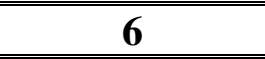 & 30 & 36 \\
\hline Trp. & 6 & 6 & 22 & 18 \\
\hline $\mathbf{S}_{1}$ & 8 & 6 & 22 & 30 \\
\hline$\overline{\mathbf{S}_{2}}$ & $\overline{6}$ & 10 & 17 & 19 \\
\hline$\overline{S_{3}}$ & $\overline{6}$ & - & 28 & 30 \\
\hline $\mathbf{S}_{4}$ & 6 & 6 & 28 & 30 \\
\hline $\mathrm{S}_{5}$ & - & 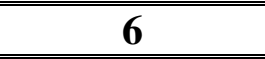 & 26 & 20 \\
\hline S6 & 10 & 6 & 18 & 15 \\
\hline $\mathbf{S}_{7}$ & 12 & 8 & 16 & 14 \\
\hline S8 & 8 & 10 & 17 & 20 \\
\hline $\begin{array}{l}\text { S9 } \\
\end{array}$ & 15 & 8 & 21 & 16 \\
\hline $\mathbf{S}_{10}$ & 8 & 8 & 18 & 11 \\
\hline & \multicolumn{2}{|c|}{$\begin{array}{c}\text { Where:- } \\
\text { 6-8 }(+) \\
\text { 8-10 }(++) \\
>10(+++)\end{array}$} & \multicolumn{2}{|c|}{$\begin{array}{c}\text { Where:- } \\
\text { 30-40 }(+++) \\
20-30(++++) \\
10-20(+++++)\end{array}$} \\
\hline
\end{tabular}


Table (5)

Minimal inhibitory concentration (MIC) for Mannich base and Trp. and their mono and mixed ligand complexes ( $\left.\mu \mathrm{gm} . \mathrm{ml}^{-1}\right)$.

\begin{tabular}{|c|c|c|c|c|c|c|c|c|c|c|c|c|c|c|c|c|}
\hline \multirow[b]{2}{*}{ Comp. } & \multicolumn{8}{|c|}{ Escherichia coli } & \multicolumn{8}{|c|}{ Staphylococcus aureus } \\
\hline & 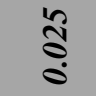 & $\stackrel{8}{8}$ & $\overrightarrow{0}$ & $\stackrel{n}{2}$ & 3 & - & $\stackrel{n}{\sim}$ & $n$ & 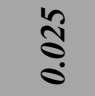 & $\stackrel{8}{8}$ & $\overrightarrow{0}$ & $\stackrel{n}{\tilde{c}}$ & ?ִ & - & ? & $n$ \\
\hline $\mathbf{E}$ & + & + & + & MIC & - & - & - & - & + & + & MIC & - & - & - & - & - \\
\hline Trp. & + & + & + & MIC & - & - & - & - & + & + & + & MIC & - & - & - & - \\
\hline $\mathbf{S}_{1}$ & + & + & MIC & - & - & - & - & - & + & + & MIC & - & - & - & - & - \\
\hline $\mathbf{S}_{2}$ & + & + & + & MIC & - & - & - & - & + & MIC & - & - & - & - & - & - \\
\hline $\mathbf{S}_{3}$ & + & + & + & MIC & - & - & - & - & + & + & + & + & MIC & - & - & - \\
\hline $\mathbf{S}_{4}$ & + & + & + & MIC & - & - & - & - & + & + & + & + & MIC & - & - & - \\
\hline $\mathbf{S}_{5}$ & + & + & + & + & MIC & - & - & - & + & + & + & + & MIC & - & - & - \\
\hline $\mathbf{S}_{6}$ & MIC & - & - & - & - & - & - & - & + & MIC & - & - & - & - & - & - \\
\hline $\mathbf{S}_{7}$ & MIC & - & - & - & - & - & - & - & MIC & - & - & - & - & - & - & - \\
\hline S8 & + & MIC & - & - & - & - & - & - & + & MIC & - & - & - & - & - & - \\
\hline S9 & MIC & - & - & - & - & - & - & - & + & + & MIC & - & - & - & - & - \\
\hline $\mathbf{S}_{10}$ & + & + & MIC & - & - & - & - & - & + & + & + & MIC & - & - & - & - \\
\hline Ampicillin & + & + & + & + & + & MIC & - & - & + & + & + & + & MIC & - & - & - \\
\hline Amoxicillin & + & + & + & + & + & + & MIC & + & + & + & + & + & + & MIC & - & - \\
\hline
\end{tabular}

\section{References}

[1].C.X. Zhang and S.I. Lippard., "Current Opinion in Chemical Biology", Tetrahedron Lett., 46(7), (2005).

[2]. N.R. Faltermeier., "Microowave assisted synthesis and antimicrobial activity of some heterocyclic derivatives", J.Serb. Chem. Soc., 80(22), (2007).

[3].R. Peter and S. Murray., "Principles of organic chemistry", Amodren and Comprehensive text for School and Colleges, $2^{\text {nd }}$ Ed., Heinman Educational Book Ltd., London, (1974).

[4].T. Geissman., "principles of organic Chemistry", 4 ${ }^{\text {th }}$ Ed., H.W. Freeman and company Sanfransisco, (1976).

[5].K. Potts., "Comprehensive heterocyclic Chemitry”, A.R., Katritzky, Ch.Ress(eds.), Vol:6 Pergamon Press, (1984).

[6].L. Paquette., "Principles of modern Heterocyclic Chemistry", Translation by F.A.Hussain, (1984).

[7].R. Acheson., "An Introduction to the chemistry", $2^{\text {nd }}$ Ed., London, (1988).
[8].J.J. Bhatt and N.C. Desai., "Synthesis and antimicrobial activities of some benzothiazole derivatives", Ind. Chem., 36, (1994).

[9].R. A. M. Al-Hasani, Ph. D. Thesis, University of Al-Nahrain, Iraq, (2004).

[10]. F. M. A. Al-Hameed, M. Sc. Thesis, University of Baghdad, Iraq, (2007).

[11]. S. Anand, J. Ind. Chem .Soc., 32, pp.816-821, (2007).

[12]. R. Tudose, E. Mosoara and V. Simulescu, J. Chem., 63(24), pp.43584366, (2010).

[13]. R.A.M. Al-Hasani and Z.A. Al-Rubaie., "mannich base derived from 1,3,4oxadiazole as chelating ligand for some transition metal complexes" Baghdad university, Iraq, Baghdad, (2007).

[14]. M.R. Atlas, E. Alfres, B. Alfres and C.P. Lawrence "Laboratory manual Experimental Microbiology", Mosby- year Book, Inc., (1995). 
[15]. S. Hogg, "Essential microbiology", 4 Ed., John- Wiely and Sons, New York, England, (2005).

[16]. V.M. Parikh "Absorption spectroscopy of organic molecules", (1974).

[17]. R.M. Silverstein, G.C. Bassler and T.G. Morrill, "Spectromteric Identification of organic compounds", $4^{\text {th }}$ Ed., John-Wiley and Sons, (1981).

[18]. R.M. Al-Hasani, J.Al-Nahrain univ., 11(2), pp.16-24, (2008).

[19]. S. Tarlok, Ind. Chem. Sci., 112(3), pp.323-329, (2000).

[20]. Z.H. Abd El-Wahab, M.M. Mashaly, and A.A. Faheim, J.Chem.Sci., 59(1), 25.(2005).

[21]. D. Dolphin and A. Wick, "Tabulation of Infrared Spectral Data", John Wiley and Sons, New York, pp.11-14, (1977).

[22]. C. Papiak, D. Harjit and K. D. Arun, J. Ind. Chem. Soc., 66, pp.550-557, (1989).

[23]. S. Chandra and A. Gautam, Russ, J. Coord. Chem., 35, (2009).

[24]. K. Nakamoto, "Infrared Spectro of Inorganic and Coordination Compounds", $6^{\text {th }}$ Ed., Wiley, Interscience, New York, (1997).

[25]. A. B. P. Lever, "Inorganic Electronic Spectroscopy", Elsevier Amstardam, (1968).

[26]. R. L. Dutta and A. Ashyamal, "Element of Magneto Chemistry", Affiliated EastWest Press, New Delhi, (1982).

[27]. Z.A.J. Al-Rubaie., M.Sc. Thesis, "Synthesis and characterization of some a new mannich bases complexes derived from 1,3,4-Oxadiazole ring of possible biological activity", Baghdad university, Iraq, Baghdad, (2007).

[28]. B.N. Figgis, "Introduction to Ligand Field", John Wiley and Sons, Int., New York, (1966).

[29]. N. Raman, S. Esthan and C. Thangaraja, J. Chem. Sci., pp.209-213, (2004).

[30]. A.S. Thakar, K.K. Simgh and K.T.Joshi., "Synthesis, Characterization of schiff bases and their metal complexes derived from 4-Acyl-1-pheny 1-3-methy 1-2-

pyrazolin- 5-ones and 2-amino -4(4'methyl phenyl) thiazol" Eur.J. Chem., pp.13961406, (2010).

[31]. M. Tyagi and S. Agrawal, J. Serb. Chem. Soc., 75(7), pp.935-941, (2010).

[32]. D. Sutton, "Electronic Spectra of transition Metal complexes" MC.Grow Hill, New York (1968).

[33]. A. C. Hiremath, M. B. Halli and N. V. Huggi, J. Ind. Chem. Soc., pp.374-376, (1986).

[34]. M.N. Hughes, "The Inorganic Chemistry of biological processes", Johan-Wiley, New York, $2^{\text {nd }} E d .,(1988)$.

[35]. C.H. Collins, and Lyne, P.M., "Microbiological methods", Butter Worth and Co.Ltd., $3^{\text {rd }}$ Ed., (1970).

[36]. J.E. Huheey, "Inorganic Chemistry, Principles of Structure and Reactivity", Harper International Edition Harper and Row, Publisheres, New York, $1^{\text {st Ed., }}$ (1972).

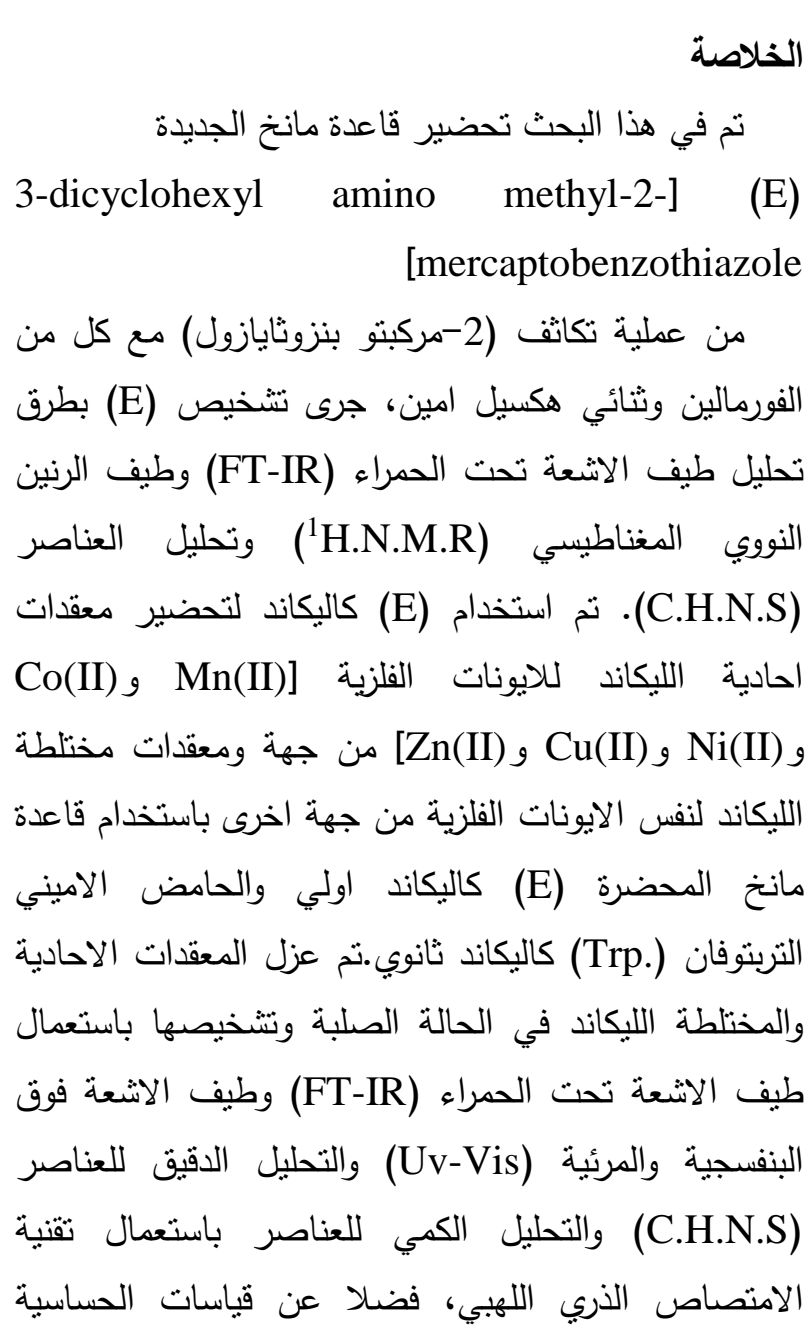


المغناطيسية والتوصيلية الكهربائية. واستتادا الى نتائج هذه

التشخيصات التي بينت ان الايونات الفلزية تنتاسق مع (E) عن طريق ذرة النتروجين لمجموعة الامينومثيل وذرة الكبريت لمجموعة الثايوكاربونيل في المعقدات الاحادية والمختلطة فضلا عن تتاسقها بال (Trp.) في المعقدات المختلطة عن فئن طريق ذرة الاوكسجين لمجموعة الكاربوكسيل وذرة النتروجين لمجموعة الامين. نم تقويم الفعالية المضادة للبكتريا لليكاندات

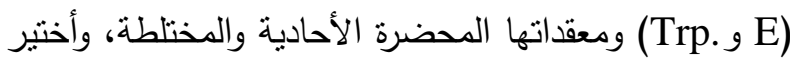

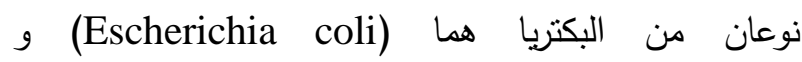
لهذا الغرض، ودراسة أقل (Staphylococcus aureus) تركيز يحدث عنده التنبيط (MIC). كما تمت مقارنة فعالية هذه المركبات المحضرة مع نوعين من المضادات الحيوية

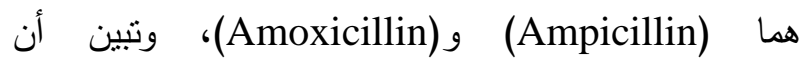
المركبات المحضرة أكثر فعالية عند مقارنتها مع المضادات الحيوية المختارة. كما تم إجراء التقويم الحيوي لليكاندات ومعقداتهم المحضرة الأحادية والمختلطة الليكاند

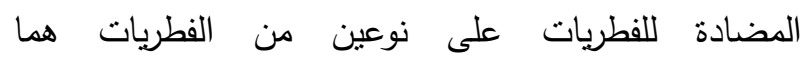
و و (Panicillum Spp.) أظهرت نتائج التقويم زيادة كبيرة في فعالية المعقدات بالمقارنة مع الليكاندات المحضرة منها، وتم تفسير الفعالية المضادة للبكتريا أو الفطريات إلى حصول التأثير المتداوب للفعالية بين الفلز والليكاند، فضلا عن الإختلاف في تراكيب المركبات

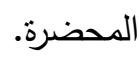

